\title{
POLITICAL PARTIES AND ELECTORAL OFFENCES IN NIGERIA \\ A Critical Analysis
}

\section{Bethel Uzoma Ihugba and Charles Alfred}

Dr. Bethel Uzoma Ihugba is Senior Research Fellow, Legal Research Division, Legislative Support Services, National Institute for Legislative and Democratic Studies, National Assembly, Abuja

Dr Charles Alfred is Research Fellow, Department of Democratic Studies, National Institute for Legislative and Democratic Studies, National Assembly, Abuja

\begin{abstract}
The paper examines the Nigerian Constitution and Electoral Act 2010 (as amended) on the role and complicity of political parties in electoral offences in Nigeria. It explores the extent to which political party activities or inactions constitute or contribute to electoral offences. The objective is to find out whether political parties are complicit in electoral offences, and whether the Electoral Act needs to be reformed to accommodate political party culpability, reduce the criminal complicity of political parties, and improve political party accountability. The paper adopts a mixed method of normative and critical analysis. Normative analysis arises from examination of doctrinal data which consist of the principles of law, provisions of the Electoral Act 2010 and the Constitution of the Federal Republic of Nigeria (CFRN) 1999 and other relevant laws regarding jurisprudence in democracy and constitutionalism, in order to determine their coherence and validity. Critical analysis, on the other hand, is applied to electoral and democratic principles in extant literature and policy in order to justify the necessity of reforming electoral laws. The paper finds that the Electoral Act is silent in many instances of potential political party complicity in electoral offences. However, the law could be reformed to improve political party accountability and reduce the incidence of electoral offences in Nigeria. It recommends some policy reforms and amendments to improve the effectiveness of the Electoral Act 2010.
\end{abstract}

Keywords: constitutional democracy, Electoral Act 2010, electoral offences, party politics, political party accountability 


\section{INTRODUCTION}

Free, fair and effective elections and a regime free of corruption are the bedrock of democracy and underpin the legitimacy, representativeness and constitutionality of government (Sisk 2017, p. 5). Conversely, disruption of the electoral process through a criminal breach of the electoral law in order to gain governmental power is counterproductive, illegitimate and unconstitutional. Political parties are the key organs that ensure the sustenance of democracy through party politics. As the only institutions empowered to sponsor candidates for elective offices in Nigeria, they must therefore do all within their legitimate power to promote and protect the rule of law through adherence to electoral laws. This is one of the key functions of political parties. In essence, when political parties do not adhere to the rule of law, especially during electoral campaigns and elections, the results will be tainted by illegality. It is the adherence to the rule of law as enunciated in the electoral laws that imbues the winning party with the legitimacy and constitutionality to govern and represent its constituency. In the same vein, if it is evident that the ruling political party acquired power by breaking the law, particularly electoral laws, this will lead to a crisis of legitimacy for the government which may in turn lead to a vicious circle of electoral violence, brigandage and lawlessness in the polity (Bader 2012, p. 53).

In Nigeria the role of political parties in electoral offences may be demonstrated by the number of electoral offences that may be or can only be committed by or in collusion with political parties and their prevalence or absence during elections. These include most of the electoral offences under Part VII of the Electoral Act 2010, where political parties are not considered to be culprits. This is a poor reflection of the Nigerian electoral system, because in a more advanced electoral system there is less possibility of such offences through the establishment of institutional frameworks that reduce their occurrences (Bader 2012, p. 53). In the same vein, and conversely, the more there are of such offences in the electoral law, without institutional frameworks to curb their occurrence, the less advanced is the electoral system. Constitutionalism thrives where both the assumption of power and the exercise of power are conducted in accordance with the constitution and the rule of law (Nwabueze 2004, p. 245). In relation to electoral systems, avoiding a criminal breach of the electoral law is the foundation of constitutionalism. Constitutionalism and the rule of law ensure that political actors subject themselves to accountability by upholding the law (rule of law); that there is a level playing field for all segments of society to participate in the governance process (representativity); and through the legal framework stipulate the criteria for the formation of government (constitutionalism) (Oyewo 2007, p. 1). 
In Nigeria there is no clear legal framework outlining the responsibility of political parties in ensuring compliance with the electoral law, particularly in relation to electoral offences. This is because although the Electoral Act of 2010 creates several offences which by their nature may be or can only be committed by or in collusion with political parties, the Act fails to include political parties as potential culprits or to assign appropriate liability and sanction. This failure to properly highlight the potential role of political parties creates the impression either that political parties can do no wrong, or where they do so they cannot be held accountable. This can also be interpreted as a tacit approval of political party lawlessness insofar as they can gain power through such means - a tacit approval of civilian coup d'état. In describing this phenomenon, the research explores the extent to which political party actions or inactions constitute or contribute to electoral offences in Nigeria. The objective is to establish whether political parties are complicit in electoral offences; whether the Electoral Act needs to be reformed to assign liability to political parties; and whether institutional frameworks on electoral offences need to be expanded to eliminate or reduce the criminal complicity of political parties.

To explore these issues, the paper is structured as follows: the next section provides conceptual definitions for key concepts that are recurrent in the research. These concepts are constitutionalism, the rule of law, electoral offences and criminal breach. This is followed by a literature review mainly on the essence of criminal law and role of the political party in elections. The intent is to situate the study in extant research and highlight the need to explore the relationship between criminal law and the role of political parties in democratisation. Next is a presentation and analysis of electoral offences in the Electoral Act 2010, their limitations and implications for the effectiveness and efficiency of the electoral process. This is followed by an analysis of the role of political parties and their relationship to electoral offences in Nigeria. The paper concludes with recommendations for improving the electoral system and laws in Nigeria.

\section{METHODOLOGY}

The paper adopts a mixed method of normative analysis and critical analysis. Normative analysis consists of analysing doctrinal data i.e. the principles of law, provisions of the Electoral Act 2010, the Constitution of the Federal Republic of Nigeria (CFRN) 1999 and other relevant legislation regarding jurisprudence in democracy and constitutionalism to determine their coherence and validity (Routio 2007; Hutchinson \& Duncan 2012). One example is determining the normative coherence of criminalising conduct committed by an individual, but not applying the same principle when committed by a group such as a political party. 
Critical analysis, on the other hand, analyses electoral and democratic principles in extant literature and policy in order to examine and apply these principles in justifying the reform of electoral laws (Rankin \& Wolfe 2019).

\section{CONCEPTUAL CLARIFICATIONS}

This section defines and justifies the value of key concepts discussed in the paper. These concepts include constitutionalism, constitutional democracy, the rule of law, party politics, electoral offences and criminal breach.

\section{Constitutionalism}

In Nigeria, the constitution (CFRN 1999) is the source and foundation of all laws. All laws, legal actions, policies and government actions find validity in this constitution. Failure to find validity in the constitution or acting contrary to the constitution invalidates or voids conduct, action or inaction (Section 1 (2) and (3) of the CFRN 1999 as amended). With particular reference to the exercise of governmental power through democratic elections, section 1(2) of the CFRN 1999 provides that: 'The Federal Republic of Nigeria shall not be governed, nor shall any persons or group of persons take control of the Government of Nigeria or any part thereof, except in accordance with the provisions of this Constitution'. In this regard, constitutionalism means the establishment and conduct of government through constitutionally established institutions, impersonal bureaucratic procedures and processes and in accordance with any statutory law (Nwabueze 2004, p. 245). This is important because it is only through adherence to constitutionalism that good governance and accountability can be ensured in government (Oyewo 2007, p. 1).

\section{Constitutional Democracy}

Constitutional democracy is the practice of democratic governance in accordance with constitutionally established principles. Whereas democracy can exist without following a constitutional mandate, constitutional democracy exists only when the dictates of the constitution are duly recognised and strictly applied in the democratic process.

\section{Rule of Law}

The rule of law is the principle that all persons and institutions are subject to the dictates of the law and the determination of such right by an impartial justice system. The adherence to the rule of law thus means the supremacy of 
the law, protection of fundamental human rights, equality before the law and an independent justice system to interpret the law (Nwabueze 1992, p. 19).

\section{Party Politics}

Democracy may exist with or without political party systems. Where political parties do not exist, candidates for electoral positions may contest on their own authority and identity. Political parties have several definitions which can be summarised to mean a group of men and women with a similar policy and target of capturing and controlling political power. However, in this paper we adopt the legal definition of a political party. According to this definition, a political party includes any association of persons whose activities includes canvassing for votes in support of candidates for election under the Act and registered by the Commission (Section 156 Electoral Act 2010). Persons who do not belong to a political party go through neither the rigour of party primaries nor sponsorship by political parties. Where political parties do exist, as is the case of Nigeria, candidates for elective positions can only be qualified to run for office when sponsored by a political party (Section 87 Electoral Act 2010). This involves campaigning within the party for nomination as a candidate and campaigning as a party candidate against other candidates from other parties for elective office. An electoral or political process where political parties are the focal points for political participation is regarded as party politics (Karp \& Banducci 2007).

\section{Electoral Offences}

Electoral offences include conduct or omission aimed at illegitimately and illegally acquiring political power, the occurrence of which attracts the criminal sanction of imprisonment, fine or both. Electoral offences are therefore offences committed in pursuance of an elective position in Nigeria. In Nigeria the Electoral Act 2010 (as amended) defines electoral offences. Accordingly, in this paper electoral offences are those acts, omissions and conduct prohibited under the Electoral Act and classified as electoral offences, particularly offences created in Part VII of the Electoral Act 2010. These include section 128 (disorderly conduct); section 129 (campaigning or soliciting votes within 300 metres of a polling booth); and section 130 (corruptly influencing any person to vote in a particular way).

\section{LITERATURE REVIEW}

The idea of corporate liability for criminal actions is fast becoming the norm in many jurisdictions (Iyidobi 2015, p. 106). Corporate criminal liability is, however, 
yet to be properly linked with electoral offences committed by political parties during elections. In Nigeria, political parties are corporate entities with separate identities from their members or managers (Section 80 Electoral Act 2010) which means that, technically, a political party may also be found guilty of committing or colluding in the commission of an electoral offence. This may happen where there is a breach of electoral provision due to the actions or inactions of a political party. Thus, if breaching electoral law is an offence, political parties may be criminally liable for actions or omissions breaching electoral laws. In other words, the culpability of political parties in electoral offences should be properly examined and highlighted to help pave the way for its elimination or reduction. However, the question arises as to whether there is justification for making political parties liable for a breach of electoral laws.

The answers to this question appear to be in the affirmative, judging by the established functions of codification of criminal law:

- Definition of conducts or omissions that are prohibited or required by a criminal law;

- Outlining the minimum conditions for culpability for a criminal offence; and

- Setting out the liability for the offence relative to its seriousness or harm caused to individual or society and culpability of the culprit (Robinson 1994).

These three functions are regarded as rule articulation, liability assignment and grading of sanction. The importance of these functions is to meet the natural law requirement that an identifiable and distinct person must be held accountable for the breach of a criminal law. In addition, such criminal law must have been explicitly provided for within extant laws and the punishment clearly stated (Section 36 (12) CFRN 1999). Without these three elements clearly outlined in the law, a criminal provision would not have met its functions.

In addition to this jurisprudential justification for criminal law, there are also socio-political reasons for the enactment of criminal laws. These rationales include the protection of the offender, punishment of the offender, and protection of the community. The law is meant to protect both the offender and victim. For the offender, it ensures that the correct person is punished and correct sanction is imposed. By clearly stipulating the rule articulation, liability assignment and grading of sanction, criminal law ensures that victims of crime do not take the law into their own hands. It recognises that the commission of crime raises negative and vengeful emotions from the injured party or interested persons and that where the victims have the capacity to do so they may seek immediate and 
mostly disproportionate revenge (Walker 1969, p. 17). The law abhors disorder, and criminal law works to maintain stability, orderliness and balance with regards to the determination and prosecution of offences. The courts, through criminal law, are able to adjudicate criminal cases and the convict is given proportionate sanctions as provided within the law (Gardner 1998, pp. 32-34).

The law also imposes punishment on the offender, the corollary to protecting the offender. The protection is limited to the extent that the offender is judicially identified, offence determined and a commensurate punishment imposed on the offender. The imposition of sanction has two different purposes. Firstly, to cause the offender to atone for the offence committed (Wood 2002) and secondly to deter and educate the offender against committing similar or any offence in the future (Husak 2004, pp. 217-218).

Aside from protecting and punishing the offender, criminal law protects the community. This position on the protection of the community is from the perspective that crime is an offence against society (community) as much as against an individual. The fact that an individual is directly harmed is immaterial. What makes it a communal affair is that members of society have relinquished the chaos of the will of the strongest, and have adopted the role and grief of an individual or community as a communal responsibility when harm is caused. Thus, by prosecuting and punishing crime, the community is protected from repeat occurrences. In this case, the community must view the actions that constitute the offence as (morally) wrong and not necessarily a political imposition by government (Robinson 2003, p. 1002). It also includes protecting the community from the harm of potential wrongdoing (Lanham et al. 2006). In other words, crime may not be committed before the law can come into action, but rather the likelihood of an offence can trigger the protection of the law.

The protection of the community and the general purpose of criminal law also overlap in various ways, particularly as instruments of deterrence, prevention or incapacitation, rehabilitation or reform, denunciation and restoration. These are all purposes of criminal law. Accordingly, flowing from the principle of corporate criminal liability, political parties as corporate bodies can and should be held accountable for electoral offences which they are proven to have tacitly encouraged, colluded in, sponsored and benefitted from. Corporate criminal liability occurs when a corporate entity commits a crime. Corporate crimes are defined as illegal acts, omissions or commissions by corporate organisations themselves as social or legal entities or by officials or employees of the corporations acting in accordance with the operative goals or standard, operating procedures and cultural norms of the organisation, intended to benefit the corporations themselves (Lederman 2001 cited in Erhaze \& Momodu 2015, pp. 63-72). 
Incidentally, in Nigeria common law provisions do not apply to crimes. An individual, organisation or body can only be held liable for a crime prescribed in a written law (Section 36(12) CFRN 1999 as amended). This means that for corporate criminal liability to apply in Nigeria, it must be statutorily provided in a law with elements of the offence and sanction clearly stated. The Nigerian legal system recognises this and has thus prescribed offences for which corporate entities and organisations may be held liable. Examples include the Terrorism Prevention Act 2013; Food and Drug Act Cap 150 LFN 1990; Standard Organization of Nigerian Act Cap S9 LFN 2004; Federal Environmental Protection Agency Act Cap 131 LFN 1990; and Oil in Navigable Waters Act Cap O6 LFN 2004. The task, however, is the feasibility of setting adequate sanction and sentencing guidelines, because it is necessary to make the sanctions and sentencing guidelines both effective and efficient. It must be effective in the sense that it has the capacity to deter, reform, and persuade corporate bodies to be law-abiding; efficient in that an optimum amount of resources, financial, material and time are deployed in achieving the desired level of effectiveness. This may mean developing a framework that leaves room for a case-by-case application of sanction to ensure that all offenders receive appropriate and effective sanctions.

Corporate criminal liability in the Nigerian legal system is yet to fully recognise the role of political parties, particularly with respect to actions and omissions that are apparently outside the constitutional and statutory purpose or duty of political parties. Examples are those offences created in Part VII of the Electoral Act 2010, such as the mutilation of the voters' register, buying of voters' cards, forgery of nomination papers and vote buying. The present language of the Electoral Act gives the impression that political parties are incapable of committing electoral offences as prescribed under the Part VII of Act, particularly in relation to offences aimed at influencing or manipulating votes. The only exceptions are offences related to political party finances, campaigns, election expenses and electoral violence in sections 88, 92, 95, 96 and 99 of the Electoral Act 2010 as amended.

However, in the offences created in Part VII which deals specifically with electoral offences, no offence is defined to assign liability to political parties. All the offences created from section 117 to 132 only contemplate individuals and associations $^{1}$ as culprits. None mentions political parties. For instance, Section 124 (6) recognises that most electoral offences are committed on the directive of

1 The term 'association' does not include 'political party'. Association and political party are clearly defined in section 156 of the Electoral Act 2010. A political party is defined as including 'any association of persons whose activities includes canvassing for votes in support of candidates for election under the Act and registered by the Commission'. Association on the other hand is defined as 'a body of persons (corporate or otherwise) who agree to act together for any common purpose and includes an association formed for ethnic, social, cultural, occupational or religious purpose'. 
another but fails to name political parties as potential culprits. It only recognises candidates. Ironically, Part VII of the Electoral Act 2010 which fails to recognise the input of political parties prescribes electoral offences that go directly to the election and which have the capacity of directly distorting the will of the electorate in favour of a benefitting political party (See sections 117 to 132 of the Electoral Act 2019).

\section{THE ROLE OF POLITICAL PARTIES IN PROMOTING CONSTITUTIONALISM, DEMOCRACY AND THE RULE OF LAW}

It is necessary to recognise the impact of political parties on electoral offences because political parties are the constitutional and statutory vehicles for democratic elections in Nigeria (Section 87 of the Electoral Act 2010). Accordingly, it is political parties and not candidates that, legally speaking, contest elections. Candidates are merely representatives sponsored by political parties (Section 87 of the Electoral Act 2010). Thus, without political parties being recognised in the contest, candidates lose their representative status. In other words, there is no independent candidate under the Nigerian electoral legal framework. Candidates, especially elected executives, may however switch parties after elections. Legislators may only do so on strict adherence to constitutional provisions of section 68(1) CFRN 1999 as amended. ${ }^{2}$

This responsibility coincides with the roles of political parties in the electoral process. The primacy of political parties in the democratic process and constitutionalism in Nigeria is demonstrated by the various functions of political parties. For instance, under the constitution, one of the key requirements for any candidate to run for any elective position, from councillorship to the presidency, is sponsorship by a political party (Ihugba \& Aaron 2018, p. 212; see also these case laws Owuru v. Adigwu [2018] 1 NWLR, p. 30, paras. G-B; Uwazuruike v. Nwachukwu, (2013) 3 NWLR (Pt. 1342) 503; Daniel v. INEC [2015] 9NWLR, pt.

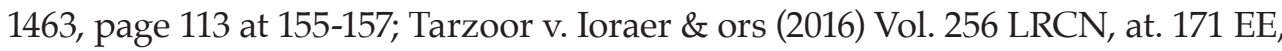
and P.D.P v. Ezeonwuka (2018) 3 NWLR, p. 198. Para.8). In other words, without political party sponsorship neither electoral offices nor government would be formed. This is evident in the provision of section 1(2) of the CFRN 1999, to the effect that the Federal Republic of Nigeria shall not be governed, nor shall any persons or group of persons take control of the Government of Nigeria or any part thereof, except in accordance with the provisions of this Constitution'. On this foundation, the constitution empowers individuals under section 40 of

2 This exception has been consistently abused by legislators. These incidences of abuse do not however represent the position of law in Nigeria but are instances of failure to enforce. Such actions do not constitute electoral offences as defined under the Electoral Act. 
the CFRN 1999 with the right to form and join political parties for purposes of forming a government. Section 221 of the CFRN 1999 clarifies this right thus: 'No association, other than a political party, shall canvass for votes for any candidate at any election or contribute to the funds of any political party or to the election expenses of any candidate at an election'.

These statutory and constitutional provisions demonstrate the importance of political parties in democracy and constitutionalism, and include:

- Sponsorship of candidates for electoral offices

- Conducting party primaries to select candidates

- Establishing the rules and regulation for internal party politics

- Conducting voter education and enlightenment on party politics

- Conducting electoral campaigns during elections

- Funding electoral campaigns

- Effective representation of diverse interests and inclusive participation in democratic governance, (OSCE Human Dimension Seminar 2011, p. 5; Bartolini \& Mair 2001), and

- Formation of government upon winning of an election (Section 1(2) of CFRN 1999; Norris 2005, pp. 3-4).

Achieving these is the essence of democratic government. Accordingly, in meeting the above objectives political parties fulfill their role as the cornerstone of democratic society (Norris 2005, p. 4).

\section{THE ROLE OF POLITICAL PARTIES IN ELECTORAL OFFENCES}

The flip side of the roles of political parties is that failure to judiciously carry out their functions in accordance with constitutional and statutory requirements leads to a breach of constitutionalism and an endorsement of criminality in the electoral process (Isma'ilaa \& Othmana 2016, pp. 296-303). Political parties must therefore be made conscious of their responsibility in sustaining democracy; however, it is counterproductive to ignore the fact that political parties are in most cases complicit in electoral malpractices. Electoral malpractices are always to the benefit of a political party and it is unhealthy for a democracy to ignore their involvement. As previously indicated, electoral malpractices include all actions and inactions, omissions and commissions aimed at illegitimately and illegally acquiring political power (Ebirim 2014, p, 51). In Nigeria these actions and inactions, omissions and commissions are constitutionally and statutorily prohibited. 
An examination of research on electoral malpractice reveals that political parties are regular culprits in committing electoral offences (Okoye 2013, p.1). For instance, it was reported that a political party was engaged in a religious campaign, contrary to the Electoral Act, by depicting another party's candidate as being from a minority religion in his constituency (Afolabi \& Avasiloae 2015, p. 25; Section 95 Electoral Act 2010). There is no report that this offence was prosecuted. There are many other reports of electoral offences by political parties which could not be prosecuted, most of which indicate that political parties encouraged illegality and electoral malpractices and offences (Afolabi \& Avasiloae 2015, p. 15; Janda 2005), both by actively encouraging party members to become violent and involved in malpractice, and failing to educate members against electoral offences (Obakhedo, 2011, p. 107).

\section{POLITICAL PARTIES AND ELECTORAL OFFENCES IN NIGERIA}

The actors in breach of the Electoral Act 2010 could be categorised into public officers, candidates, political parties, associations and individuals. In order to effectively curtail and sanction electoral offences by any of these groups, the liability assignment element of the offence must anticipate all potential actors, including those aiding and abetting, in the commission or omission against the Act. Such liability assignment can be determined by considering the objectives of the perpetrators of these offences (Robinson 1994).

This requires the accurate identification of potential perpetrators, (i.e. liability assignment) to ensure that all potential actors are captured in the law. An absence of this may render the law ineffective because if perpetrators cannot be sanctioned the deterrence objective of the law will be lost (Ikeme, Udefuna \& Ihugba 2018, p. 3). An examination of the Electoral Act 2010, in particular electoral offences as created under Part VII which contains sections 117 to 132, and specifically, sections 96, 99 and 102, reveals a failure to capture political parties. Evidence however suggests that most of these offences can be and usually are committed in collaboration with political parties (Okoye 2013, p. 1). For instance, with regards to offences committed in collusion with party officials, a study of the trend in electoral disputes arising from electoral offences found that the percentage of offence sponsored by state and political party officials rose from $33.33 \%$ in $2003,69.44 \%$ in 2007 to $76.92 \%$ in 2011 (Ihugba, Alfred \& Ejalonibu 2018, p. 4). This demonstrates that the failure to anticipate party involvement in electoral offences and provide sanctions against such involvement is a considerable obstacle to eliminating illegality in elections.

The implication of this failure is further demonstrated by the complicity of political parties in most electoral offences created under the Electoral Act 2010. The complicity in this instance is hinged on both the potential benefit they derive 
from the offences and their failure to instil party discipline and fulfill their statutory and political functions in the democratic process. See Table 1 below for an illustration of this complicity.

Table 1: Electoral offences and suggested liability

\begin{tabular}{|c|c|c|c|}
\hline $\mathbf{S} / \mathbf{N}$ & $\begin{array}{l}\text { OFFENCES UNDER THE } \\
\text { ELECTORAL ACT } 2010 \\
\text { as amended }\end{array}$ & $\begin{array}{l}\text { PROPOSED LIABILITY } \\
\text { ASSIGNMENT/REVIEW }\end{array}$ & REMARKS \\
\hline 1 & $\begin{array}{l}\text { Directly or indirectly } \\
\text { using force or violence } \\
\text { during a political } \\
\text { campaign }\end{array}$ & $\begin{array}{l}\text { This provision should } \\
\text { be redrafted to impose } \\
\text { serious sanctions against } \\
\text { political parties. A } \\
\text { mere fine is insufficient, } \\
\text { sanctions should include } \\
\text { disqualification of the } \\
\text { political party and its } \\
\text { candidate, especially } \\
\text { where there is a repeat } \\
\text { offence. }\end{array}$ & $\begin{array}{l}\text { In most instances, reports } \\
\text { indict political parties and } \\
\text { not individuals (Verjee, } \\
\text { Kwaja, \& Onubogu 2019, } \\
\text { pp. 16-17) which suggests } \\
\text { that sanctions should be } \\
\text { a sufficient deterrent to } \\
\text { political parties. Political } \\
\text { parties should also be } \\
\text { required to provide for } \\
\text { sanctions, in the party } \\
\text { constitution, against } \\
\text { candidates or members } \\
\text { who engage in violence } \\
\text { during elections. }\end{array}$ \\
\hline 2 & $\begin{array}{l}\text { Campaigning through any } \\
\text { persons more than } 90 \text { days } \\
\text { before the polling day and } \\
\text { campaigning less than } 24 \\
\text { hours before polling day. }\end{array}$ & $\begin{array}{l}\text { Sanctions should be } \\
\text { increased against a } \\
\text { political party if an } \\
\text { offence is committed } \\
\text { on its directive or with } \\
\text { its knowledge and / or } \\
\text { consent. The maximum } \\
\text { fine of N500, } 000 \text { is } \\
\text { insufficient and should } \\
\text { be increased to include } \\
\text { disqualifying the party. }\end{array}$ & $\begin{array}{l}\text { Party should be able to } \\
\text { ensure that no candidate } \\
\text { sponsored by them } \\
\text { contravenes the law. }\end{array}$ \\
\hline 3 & $\begin{array}{l}\text { Campaigning based } \\
\text { on religious, tribal or } \\
\text { sectional grounds for the } \\
\text { purpose of promoting or } \\
\text { opposing a candidate or a } \\
\text { party by a person or party. }\end{array}$ & $\begin{array}{l}\text { Political parties should } \\
\text { also be held liable if the } \\
\text { offence is committed } \\
\text { on the directive, with } \\
\text { the consent, approval } \\
\text { or knowledge of a } \\
\text { political party. Due } \\
\text { to the implication of } \\
\text { causing long-term and } \\
\text { post-election religious } \\
\text { divisions, sanctions } \\
\text { should also be increased. }\end{array}$ & $\begin{array}{l}\text { This is contrary to the } \\
\text { constitutional right to } \\
\text { freedom of religion } \\
\text { (Onapajo 2016, pp. 122- } \\
\text { 3). Accordingly, political } \\
\text { parties should be held } \\
\text { responsible for failing to } \\
\text { control their candidates } \\
\text { and members. }\end{array}$ \\
\hline
\end{tabular}




\begin{tabular}{|c|c|c|c|}
\hline 4 & $\begin{array}{l}\text { Using government or } \\
\text { public corporations' } \\
\text { vehicles in a manner other } \\
\text { than for an emergency by } \\
\text { an electoral officer or for } \\
\text { transporting those entitled } \\
\text { to such vehicle. }\end{array}$ & $\begin{array}{l}\text { Where committed by } \\
\text { officers of a political party } \\
\text { or with its knowledge } \\
\text { and consent, the political } \\
\text { party and the candidate } \\
\text { should be sanctioned. } \\
\text { This achieves two } \\
\text { objectives: (a) it ensures } \\
\text { a level playing field, and } \\
\text { (b) ensures that public } \\
\text { funds are not diverted to } \\
\text { political party campaigns. }\end{array}$ & $\begin{array}{l}\text { This is most likely to } \\
\text { happen with ruling } \\
\text { parties or incumbents. }\end{array}$ \\
\hline 5 & $\begin{array}{l}\text { Directly, indirectly or } \\
\text { through a proxy conspires, } \\
\text { bribes or aids and abets } \\
\text { any party in order to } \\
\text { procure the return of a } \\
\text { candidate to any elected } \\
\text { office. }\end{array}$ & $\begin{array}{l}\text { Where committed by } \\
\text { officers of a political party } \\
\text { or with the knowledge } \\
\text { and consent of a } \\
\text { candidate, the political } \\
\text { party and the candidate } \\
\text { shall be disqualified from } \\
\text { the election. This offence } \\
\text { is directly contrary to the } \\
\text { functions of governance. }\end{array}$ & $\begin{array}{l}\text { This type of offence } \\
\text { is unlikely to have } \\
\text { been committed by an } \\
\text { individual without party } \\
\text { support or assistance } \\
\text { (Aluaigba 2016, p. 143) }\end{array}$ \\
\hline 6 & $\begin{array}{l}\text { Inciting others to act in a } \\
\text { disorderly manner }\end{array}$ & $\begin{array}{l}\text { Political parties to be held } \\
\text { liable if the offence is } \\
\text { committed by officers of a } \\
\text { political party or with the } \\
\text { knowledge and consent } \\
\text { of a candidate or political } \\
\text { party. }\end{array}$ & $\begin{array}{l}\text { Parties are repeatedly } \\
\text { indicted for this type of } \\
\text { offence (Verjee, Kwaja, } \\
\text { \& Onubogu 2019, pp. } \\
\text { 16-17). }\end{array}$ \\
\hline 7 & $\begin{array}{l}\text { Solicits, canvasses, } \\
\text { persuades, campaigns, } \\
\text { promotes any candidate } \\
\text { within } 300 \text { metres of the } \\
\text { polling unit on election } \\
\text { day, snatches or destroys } \\
\text { electoral materials, blares } \\
\text { siren, convenes, hold } \\
\text { or attends a meeting } \\
\text { (unless prescribed by the } \\
\text { commission) within } 300 \\
\text { meters of the polling unit } \\
\text { on election day. }\end{array}$ & $\begin{array}{l}\text { Political parties to be held } \\
\text { liable if committed by } \\
\text { officers of a political party } \\
\text { or with the knowledge } \\
\text { and consent of a candidate } \\
\text { or party. } \\
\text { Political parties should } \\
\text { demonstrate that there } \\
\text { is a rule against such } \\
\text { behaviour and that } \\
\text { candidates and members } \\
\text { have been duly educated. }\end{array}$ & $\begin{array}{l}\text { This type of offence is } \\
\text { usually committed by } \\
\text { party agents. Accordingly, } \\
\text { parties should be held } \\
\text { responsible (Onwe et al. } \\
\text { 2015, p. 14). }\end{array}$ \\
\hline
\end{tabular}




\begin{tabular}{|c|c|c|c|}
\hline 8 & $\begin{array}{l}\text { Giving or providing or } \\
\text { paying money to or for } \\
\text { any person to corruptly } \\
\text { influence the person } \\
\text { to vote or refrain from } \\
\text { voting. }\end{array}$ & $\begin{array}{l}\text { Where committed by } \\
\text { officers of a political party } \\
\text { or with the knowledge } \\
\text { and consent of a } \\
\text { candidate, the party and } \\
\text { the candidate should be } \\
\text { sanctioned. }\end{array}$ & $\begin{array}{l}\text { Vote buying and related } \\
\text { offences are usually } \\
\text { committed in collusion } \\
\text { with or knowledge of } \\
\text { political parties, their } \\
\text { candidates and agents } \\
\text { (Alagbe 2019; Aluaigba } \\
\text { 2016, p. 143). }\end{array}$ \\
\hline 9 & $\begin{array}{l}\text { Directly or indirectly } \\
\text { by proxy threatens, } \\
\text { uses violence, inflicts } \\
\text { injury, abducts, restrains, } \\
\text { impedes, uses duress } \\
\text { on another to hinder } \\
\text { him/ her from voting or } \\
\text { contesting in an election } \\
\text { and preventing political } \\
\text { aspirants from free use of } \\
\text { the media, mobilising or } \\
\text { campaigning. }\end{array}$ & $\begin{array}{l}\text { Where committed by } \\
\text { officers of a political } \\
\text { party or with the } \\
\text { knowledge and consent } \\
\text { of a candidate or political } \\
\text { party, the political party } \\
\text { and candidate should } \\
\text { be disqualified from the } \\
\text { election. } \\
\text { This will help highlight } \\
\text { the role of political } \\
\text { parties in educating their } \\
\text { candidates and members } \\
\text { on the ills of electoral } \\
\text { malpractices and violence. }\end{array}$ & $\begin{array}{l}\text { In most instances, reports } \\
\text { indict political parties } \\
\text { and not individuals } \\
\text { (Leibowitz \& Ibrahim } \\
\text { 2013, p. 20). }\end{array}$ \\
\hline
\end{tabular}

Source: Author's analysis of Electoral Act 2010.

\section{Consequences of Ineffective Liability Assignment in the Electoral Act 2010}

The failure to assign liability to political parties for electoral offences creates a perception of impunity (Okoye 2013, p. 8). This perception of impunity, aggravated by the consistent failure of Independent National Electoral Commission (INEC) to prosecute offenders and the failure of the Act to assign liability to political parties, may be a key factor in the continuous increase in reported electoral offences, especially those which political parties have either aided, colluded or sponsored (ibid.).

It also negates, in its entirety, the constitutionality and democratic principles of elections. Elections should be the basis for establishing fundamental laws that promote constitutionality for the benefit of the citizenry. Where this is abused through the illegitimate investiture of a political party, the principle of the rule of law would be jeopardised and constitutional democracy negated.

In addition, this may cause the shift of political accountability from citizens to political parties, mostly in the interests of the few that control the political parties (Verjee, Kwaja, \& Onubogu 2019, pp. 13-14). Where this accountability shift occurs: 
- political power tends to be acquired illegitimately through abuse of electoral laws

- the rule of law is jettisoned and electoral abuse legitimised

- legitimate and effective opposition incapacitated, and

- a vicious circle is established of power acquisition and nonaccountability in the political process.

These impact negatively on both constitutional democracy and political representation. Constitutional democracy would have been defeated because instead of acquiring political power and the right to form government in accordance with the constitution and the law, the government would have been formed in contradiction to the provisions of the constitution (section 1(2) CFRN 1999 as amended).

A breach of constitutional democracy, via ascension into power through electoral offences, also amounts to a breach of the rule of law. This is because the rule of law implies that everybody abides by the provision of the law and that upon breach of such law an independent judiciary is able to determine and impose liability (Oyewo 2007, p. 1). In relation to electoral offences, this means the capacity for the electoral management body or relevant authority to prosecute electoral offenders and for the electoral tribunal to determine whether power was acquired through the breach of electoral laws and the constitution.

Regarding political representation, acquiring political power by committing electoral offences means that the will of the electorate would be subverted and the result would not represent the vote, that is the choice of the electorate. As a consequence, the 'winners' may not see themselves as representatives of the electorate but rather as representatives of their own interests and of those persons who aided in the subversion of the public will (Aluaigba 2016, p. 150).

The implications of failing to assign criminal liability to political parties and thereby institutionalising a breach of the electoral law as identified makes the case for an urgent reform of the electoral laws, particularly in relation to electoral offences. The essence of electoral law is to establish a lawful standard and procedure for forming government in accordance with the constitution. If this objective fails because of a failure to update and reform the electoral laws by assigning liability and imposing sanctions to all culprits, particularly political parties, the consequence is the failure of democracy.

\section{FRAGILE NATURE OF POLITICAL PARTIES AND PUNISHMENT FOR ELECTORAL OFFENCES}

Generally, political parties contribute to democratic governance by aggregating and representing the interests of constituents (National Democratic Institute 2014). 
Hence, political parties should be treated with care as democratic consolidation continues, and this includes the development of electoral frameworks that punishes parties for electoral offences. While it is cogent to assert that the failure to anticipate party involvement in electoral offences is a substantial obstacle to eliminating illegality in the electoral process, it is equally important to note that political parties are still fragile entities. Unmeasured punishment of political parties and their members may impact negatively on the trust and confidence citizens invest in them. This may also reflect on the legitimacy of political parties and their capacity to perform their supposed functions in the democratic process. The intention of liability assignment should be to improve the quality of political parties and not only to use punishment as a deterrent (Robinson 2003, p. 1002).

Thus, as illustrated in the most recent World Values Survey, (see Figure 1 below) the public's declining affinity for political parties also affects virtually all mature democracies.

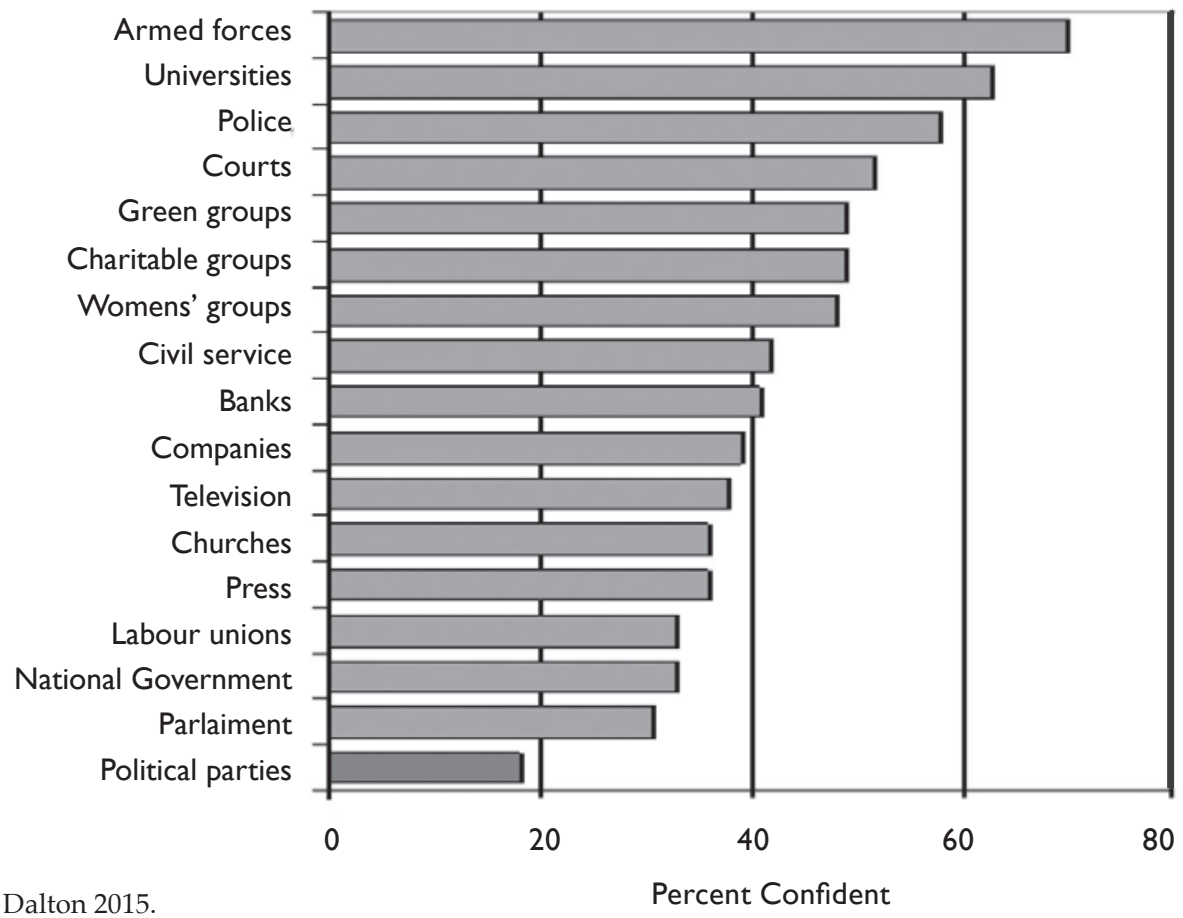

Source: Dalton 2015.

Figure 1. Confidence in social and political institutions 
Data from Figure 1 above shows that worldwide confidence in political parties is less than $19 \%$. While political parties in Nigeria need to be included in the prevention of electoral violence, this ascription of responsibility should be measured to avoid further decline in political party perception and relevance.

\section{CONCLUSION AND RECOMMENDATION}

The most important functions of elections are legitimacy, accountability, constitutionality and representative government. Where elections are conducted in disregard of the constitutionally established standards and laws, it implies a rejection or failure of these objectives. Avoiding this requires the establishment of a comprehensive body of law that reduces the opportunity for electoral impunity and does not create loopholes for the abuse of the electoral process. With particular reference to Nigeria and the electoral offences discussed in this paper, this failure could be avoided by updating the Electoral Act 2010, institutions and process of elections in the following ways:

- The law-making process should be inclusive and incorporate the views of all segments of society in order to create awareness on the intents and purposes of the electoral law, improve its legitimacy and deter any breach of the Electoral Act.

- All potential direct beneficiaries of a breach of the electoral offences should be properly defined in the law through the principle of assigning liability and imposing an appropriate sanction for the breach.

- Political parties should be specifically defined in the law to make them accountable for electoral offences and subject to sanctions introduced to deter political parties from electoral offences, or to punish a breach.

- Political parties should be required to establish policies, rules and regulations aimed at deterring candidates, party members and agents from participating or encouraging electoral offences.

- An independent tribunal or court should be established to prosecute electoral offences. This will help highlight the importance of prosecuting electoral offences and develop a body of knowledge and practice in the control of electoral offences.

- The electoral management body and political parties should, as part of their statutory functions, carry out regular sensitisation programmes and conduct events to discuss the ills and illegality of electoral offences. 
The Electoral Act 2010 and the electoral offences contained therein are all aimed at achieving a sustainable democracy in Nigeria. Electoral offences stipulate the standards and limits which parties and other electoral stakeholders must observe in their pursuit of political power. The intent is to create a positive environment through setting procedural and substantive standards for achieving the critical objectives of democratic elections, viz: representativeness, legitimacy, constitutionality and accountability. However, these objectives cannot be achieved with an inadequate electoral law. There is thus an urgent need to reassess the electoral offences and reform them to be holistic, effective and efficient in educating the citizenry and reducing (if not eliminating) electoral offences in Nigeria.

\section{----- REFERENCES --_--}

Afolabi, B \& Avasiloae, S 2015, Post-election assessment of conflict prevention and resolution mechanisms in Nigeria: Final report, Centre for Humanitarian Dialogue, November, viewed 25 March 2019, http://www.hdcentre.org/wp-content/ uploads/2016/06/Post-election_assessment_of_conflict_prevention_ and_resolution_mechanisms_in_Nigeria.pdf

Alagbe, J 2018, 'Vote-buying, a danger to Nigeria's budding democracy', Punch Online Viewed 28 April 2019, https://punchng.com/vote-buying-a-danger-to-nigerias-budding-democracy /

Aluaigba, MT 2016, 'Democracy Deferred: The Effects of Electoral Malpractice on Nigeria's Path to Democratic Consolidation', Journal of African Elections, vol. 15, no. 2.

Bader, M2012, 'Trends and patterns in electoral malpractice in post-soviet Eurasia', Journal of Eurasian Studies, vol. 3, no. 1, viewed 28 April 2019, https: / / www. researchgate.net/publication/251718758_Trends_and_patterns_in_electoral_malpractice_in_post-Soviet_Eurasia

Bartolini, S \& Mair, P 2001, 'Challenges to Contemporary Political Parties', in L Diamond \& R Gunther, eds., Political Parties and Democracy, Johns Hopkins University Press, Baltimore.

Ebirim SI 2014, 'The Effects of Electoral Malpractices on Nigeria Democratic Consolidation (1999-2013)' Public Policy and Administration Research, vol.4, no.2, viewed 27 April 2019, https://www.iiste.org/Journals/index.php/ PPAR/article/viewFile/11086/11387

Gardner, J 1998, 'Crime: in Proportion and Perspective' in A Ashworth \& M Wasik (eds), Fundamentals of Sentencing Theory: Essays in Honour of Andrew von Hirsch, Clarendon Press, Oxford.

Husak, D 2004, 'The Criminal Law as Last Resort', Oxford Journal of Legal Studies, vol. 24 , issue 2. 
Hutchinson, T \& Duncan, NJ 2012, 'Defining and Describing What We Do: Doctrinal Legal Research', Deakin Law Review, vol. 17, no. 1.

Ihugba, BU, \& Aaron, DD 2018, 'Exclusion and Electoral Laws in Nigeria: A Critical Analysis', NILDS Journal of Law Review, vol. 1, no. 1, viewed 1 October 2019, http:/ / nils.gov.ng/themes/nils/newnils/dlss_journals/1.pdf

Ihugba, BU, Charles, A \& Ejalonibu, GL 2018, 'Electoral Disputes and Violations of

Electoral Laws in Nigeria: Legislative implications', Issue Brief, 24 September 2018, NILDS.

Ihugba, BU \& Charles, A 2018, 'Legality of Defection and Implications for Democratic Consolidation in Nigeria', Legal Issue Brief, issue 1, no. 4, viewed 30 April 2019, http:/ / nils.gov.ng/themes/nils/newnils/dlss_lb / 4.pdf

Ikeme, I, Udefuna, P, \& Ihugba, BU 2018, 'Effectiveness of Sanctions and Enforcement of Electoral Offences in the Electoral Act 2010', vol.1 (Public/ Security Officers, Political Parties and Candidates), Post-Legislation Scrutiny, National Institute for Legislative and Democratic Studies, Abuja.

Isma'ila, Y \& Othman, Z 2016, 'Electoral Malpractice and the Challenges of Democratic Consolidation in Nigeria's Fourth Republic', International Review of Management and Marketing, vol. 6.

Iyidobi, CN, 2015, 'Rethinking the Basis of Corporate Criminal Liability in Nigeria', Nigerian Juridical Review, vol. 13.

Janda, K 2005, 'Political Parties and Democracy in Theoretical and Practical Perspectives: Adopting Party Law', National Democratic Institute for International Affairs, viewed 27 March 2019,http:/ /www.eods.eu/library/ NDI.Political\%20Parties\%20And\%20Democracy\%20In\%20Theoretical\%20 And\%20Practical\%20Perspectives.pdf

Karp, JA \& Banducci, SA 2007, 'Party Mobilization and Political Participation in New and Old Democracies' Party Politics, vol. 13, no. 2, viewed 4 April 2019 http: / /www.jkarp.com/pdf/pp_2007.pdf and http:/ / ppq.sagepub.com/ content $/ 13 / 2 / 217$

Lanham, D, Bartal, B, Evans, R, \& Wood, D 2006, 'Criminal Laws in Australia, Chapter 1B:The Purposes of Criminal Law', Federation Press, viewed 25 March 2019, https: / / www.federationpress.com.au/pdf/Lanham\%20Ch1B.pdf

Lederman, E 2001, 'Models for Imposing Corporate Criminal Liability: from Adaptation and Imitation Towards Aggregation and Search for SelfIdentity', Buffalo Criminal Law Review, vol. 4, 661-666, cited in Erhaze, S \& Momodu, D 2015, 'Corporate Criminal Liability: Call for a New Legal Regime in Nigeria' Journal of Law and Criminal Justice, vol. 3, no. 2, pp. 63-72. Liebowitz, J \& Ibrahim, J 2013, 'A Capacity Assessment of Nigerian Political Parties', Democratic Governance for Development (DGD) Programme, UNDP, Nigeria, viewed 27 April 2019, https:/ / www.undp.org/content/dam/nigeria/docs / DGD/dgd_assessment_of_political_parties.pdf 
Menocal, AR 2011, 'Why electoral systems matter: an analysis of their incentives and effects on key areas of governance', Overseas Development Institute (ODI), viewed 4 April 2019, https://www.odi.org/sites/odi.org.uk/files/odiassets / publications-opinion-files/7367.pdf

National Democratic Institute, 2014, Political Party Programming Guide, NDI, Washington, DC.

Nwabueze, B 1992, Military Rule and Constitutionalism, Spectrum Books, Ibadan.

Nwabueze, B 2004, Constitutional Democracy in Africa, vol.1, Spectrum Books, Ibadan.

Norris, P 2005, Political Parties and Democracy in Theoretical and Practical Perspectives: Developments in Party Communications, National Democratic Institute for International Affairs, Washington, DC. Viewed 4 April 2019, https:/ / sites. hks.harvard.edu/fs / pnorris / Acrobat/NDI\%20Final $\%$ 20booklet $\% 20-\% 20$ Communications.pdf

Obakhedo, NO 2011, 'Curbing Electoral Violence in Nigeria: The Imperative of Political Education', International Multidisciplinary Journal, Ethiopia, vol. 5, no. 5, serial no 22, http://dx.doi.org/10.4314/afrrev.v5i5.9

Okoye, F 2003, 'The Prosecution of electoral offenders in Nigeria: Challenges and Possibilities', Discussion Paper No. 5, September, p. 1, viewed 16 April 2019, https:/ / library.fes.de/pdf-files/ bueros/nigeria/10405.pdf

Onapajo, H 2016, 'Politics and the Pulpit: The Rise and Decline of Religion in Nigeria's 2015 Presidential Elections', Journal of African Elections, vol. 15, no. 2, viewed 3 April 2019, https:/ / www.eisa.org.za/pdf/JAE15.2Onapajo.pdf Onwe, SO, Nwogbaga, DME, \& Ogbu, MO 2015, 'Effects of Electoral Fraud and Violence on Nigeria Democracy: Lessons from 2011 Presidential Elections', Journal of Humanities and Social Science (IOSR-JHSS), vol. 20, Issue 4, viewed 27 April 2019, http://iosrjournals.org/iosr-jhss/papers/Vol20-issue4/ Version-1/C020411015.pdf

OSCE Human Dimension Seminar, 2011, 'The Role Of Political Parties In The Political Process', Office of Democratic Institutions and Human Rights, Consolidated Summary Warsaw, 18-20 May, viewed 26 March, https: / /www.osce.org/ odihr / 80984?download=true

Oyelowo, O 2007, 'Constitutionalism and the Oversight Functions of the Legislature in Nigeria', Paper presented at African Network of Constitutional Law Conference on Fostering Constitutionalism in Africa, Nairobi, April 2007, viewed 4 April 2019, https:/ / www.ancl-radc.org.za/sites/default/files/ Constitutionalism $\% 20$ and $\% 20$ the $\% 20$ Oversight $\% 20$ Functions $\% 20$ of $\% 20$ the $\% 20$ Legislature $\% 20 \mathrm{in} \% 20$ Nigeria $\% 20$ by $\% 20$ Oyelowo $\% 20$ Oyewo $\% 20$. pdf

Pentti, R 2007, Normative Analysis and Preparing the Proposal, August 3, Viewed 1 April 2019, http: / / www2.uiah.fi/ projects/ metodi/179.htm\# process 
Rankin, K \& Wolfe, S 2019, Critical Analysis Template, Writing Centre, Thompson Rivers University, Viewed 17 March 2019, https: / /www.tru.ca/_shared / assets /Critical_Analysis_Template30565.pdf

Robinson, PH 1994, 'A Functional Analysis of Criminal Law', Faculty Scholarship Paper 610, Northwestern University Law Review, viewed 4 April 2019, http: / / scholarship.law.upenn.edu/faculty_scholarship / 610

Robinson, PH 2003, 'The Role of Deterrence in the Formulation of Criminal Law Rules: At Its Worst When Doing Its Best', Faculty Scholarship, Paper 56, viewed 25 March 2019, http:// scholarship.law.upenn.edu/faculty_scholarship/56

Russell, D 2016, Myth busters: Political Parties and Democratic Decline?, Center for the Study of Democracy, University of California, Irvine, viewed 25 March 2019 https:/ /21cparties.org/post/142247235698/mythbusters-politicalparties-and-democratic

Sisk, TD 2017, 'Elections, Electoral Systems and Party Systems', International Institute for Democracy and Electoral Assistance, viewed 27 April 2019, http: / / www.idea.int/gsod

Suleh-Yusuf, M 2017, 'Criminal liability of corporate persons in Nigeria', International Journal of Law, vol. 3, issue 4.

Verjee, A, Kwaja, C \& Onubogu, O 2019, 'Nigeria's 2019 Elections: Change, Continuity, and the Risks to Peace', Special Report, United States Institute of Peace, Viewed 29 April 2019, https://www.usip.org/sites/default/ files/2018-09/sr_429_verjee_et_al_final.pdf

Vile, MJC 1967, 'Constitutionalism and the Separation of Powers', Online Library of Liberty, A Project of Liberty Fund, viewed 30 April 2019. http://lfoll. s3.amazonaws.com/titles/677/Vile_0024_EBk_v6.0.pdf

Walker, N 1969, 'Sentencing in a Rational Society', Allen Lane Penguin Press, [London].

Wood, D 2002, 'Retribution, Crime Reduction and the Justification of Punishment', Oxford Journal of Legal Studies, vol. 22, no. 2. 